\title{
Effects of Thymol, Eugenol and Malate on In vitro Rumen Microbial Fermentation
}

\author{
Do Hyung Kim*, Kyoung Hoon Kim*, Chang Won Choi*, Seong Koo Hong*, Yong Joo Seol*, Eung Gi Kwon*, \\ Wan Young Kim**, In Sik Nam***, Sung Sill Lee**** and Young Kyoon Oh* \\ National Institute of Animal Science, RDA*, Korea National Agricultural College**, \\ Korea Livestock Products HACCP Accreditation Service***, \\ Division of Applied Life Science (BK21 Program), Graduate School of Gyeongsang National University****
}

\begin{abstract}
The purpose of this study was to investigate effects of increased levels of eugenol, thymol and malate on $\mathrm{pH}$ and the concentrations of VFA, lactate and ammonia-N during in vitro ruminal incubation. One Hanwoo beef steer (741 kg) fitted with a rumen cannula was used and fed $0.5 \mathrm{~kg}$ /day rice straw and $10 \mathrm{~kg} /$ day corn-based concentrate (ratio of concentrate to rice straw = $95: 5$ on DM basis). Three different doses of thymol, eugenol and malate were used. Treatments of the experiment were as follows: Treatments of thymol were control (1g D-glucose/40ml), T1 (1g D-glucose $+40 \mathrm{mg}$ thymol/40 ml), T2 (1g D-glucose +50 $\mathrm{mg}$ thymol$/ 40 \mathrm{ml})$ and $\mathrm{T} 3(1 \mathrm{~g} \mathrm{D}$-glucose $+60 \mathrm{mg}$ thymol/40 ml). Treatments of eugenol were control $(1 \mathrm{~g} \mathrm{D}$-glucose/40 $\mathrm{ml})$, E1 $(1 \mathrm{~g}$ D-glucose $+55 \mathrm{mg}$ eugenol $/ 40 \mathrm{ml})$, E2 $(1 \mathrm{~g} \mathrm{D}$-glucose $+65 \mathrm{mg}$ eugenol $/ 40 \mathrm{ml})$ and E3 $(1 \mathrm{~g} \mathrm{D}$-glucose $+75 \mathrm{mg}$ eugenol/40 ml). Treatments of malate were control (1g D-glucose $/ 40 \mathrm{ml}), \mathrm{M} 1$ (1g D-glucose $+25 \mathrm{mg}$ malate/40ml), M2 (1g D-glucose $+50 \mathrm{mg} \mathrm{malate} / 40 \mathrm{ml})$ and M3 (1g D-glucose $+100 \mathrm{mg}$ malate $/ 40 \mathrm{ml}$ ). The results of this study showed that eugenol and thymol have improved stability of the ruminal fermentation by decreasing lactic acid concentration and increasing ruminal pH. However, it inhibited the production of total VFA, acetate and propionate. Malate also improved stability of the ruminal fermentation by decreasing lactic acid concentration and increasing ruminal $\mathrm{pH}$, but it had a very little effect on ruminal lactate concentrations and $\mathrm{pH}$. On the other hand, malate did not decrease the concentrations of total VFA, acetate and propionate. Therefore, at the low ruminal $\mathrm{pH}$ expected in high-concentrate diets, thymol, eugenol, and malate are potentially useful in Hanwoo finishing diets. Further studies are necessary for determining the effectiveness of these additives on in vivo rumen fermentation and animal performance in Hanwoo finishing steers.
\end{abstract}

(Key words : Eugenol, Thymol, Malate, Rumen fermentation)

\section{INTRODUCTION}

The purpose of feeding managements in the finishing phage of Hanwoo beef cattle is to increase marbling score. For this reason, the general feeding management of Hanwoo cattle during the fattening period is to feed a high-concentrate (above 90\%) diet or even all concentrate diet (Rural Development Administration, 2007). But, this causes a problem of decreasing ruminal $\mathrm{pH}$. The normal ruminal microflora can be greatly altered, resulting in increasing a population of acid tolerant, lactic acid producing bacteria (Slyter, 1976), and sometimes cause excessive lactic acid accumulation (Russell and Hino, 1985; Dawson et al., 1997). Lactic acid accumulation occurs when abrupt introduction of rapidly fermentable carbohydrate stimulates proliferation of the rapidly growing lactic acid producing bacterium, Streptococcus bovis, so that it exceeds the growth rate of lactic acid-utilizing bacteria (Russell and Hino 1985; Dawson and Allison, 1988). As a result of the imbalance between production and utilization, an accumulation of lactic acid occurs, but often only in specific individuals. The factors (microbial or otherwise) that may predispose certain animals to lactic acid accumulation remain largely unknown (Bevans et al., 2005).

Plant extracts have been used for centuries for various purposes as traditional medicine and food preservatives due to their antimicrobial properties (Busquet et al., 2006; Davidson and Naidu, 2000). Essential oils are blends of secondary metabolites obtained from the plant volatile fraction by steam distillation (Gershenzon and Croteau, 1991). Beginning from the report of Borchers (1965), the potential benefit of essential oil have been evaluating on rumen microbial fermentation. Rumen microbial 
activity was affected by use of plant extracts and secondary plant metabolites (Bysquet et al., 2006). It has been reported that terpenoid and phenolic components were responsible for the antibacterial properties of many essential oils (Panizzi et al., 1993; Helander et al., 1998; Chao et al., 2000; Dorman and Deans, 2000; Benchaar et al., 2007). Among these essential oils, eugenol and thymol have been shown to alter the rumen fermentation by decreasing lactic acid and increasing ruminal $\mathrm{pH}$ (Castillejos et al., 2006; Evans and Martin, 2000).

Malate is a four-carbon dicarboxylic acid that is commonly found in biological tissues because it is an intermediate of the citric acid cycle(Lehninger, 1975). Malate stimulates lactate uptake by Selenomonas ruminantium, the main lactic acid using bacteria within the rumen, so improves the ruminal $\mathrm{pH}$ and increases propionate production (Callaway and Martin, 1996; Martin, 1998). The stimulatory effects of malate on lactic acid fermentation have been clearly demonstrated in vitro (Nisbet and Martin, 1994; Martin and Streeter, 1995; Callaway and Martin, 1996). As a key intermediate in the succinate-propionate pathway, malate enhances lactic acid fermentation by Selenomonas ruminantium (Montano et al., 1999).

Research for dietary additives that help to rumen fermentation stability in Hanwoo finishing cattle consuming a high-concentrate diet has received little attention. Therefore, the objective of this study was to investigate effects of increased levels of eugenol, thymol and malate on $\mathrm{pH}$ and the concentrations of VFA, lactate and ammonia-N during in vitro ruminal incubation.

\section{MATERIALS AND METHODS}

\section{Animals, diet and feedstuffs}

One Hanwoo beef steer $(741 \mathrm{~kg}$ ) fitted with a rumen cannula (Bar Diamond, Parma, ID, USA) was used and fed $0.5 \mathrm{~kg} /$ day rice straw and $10 \mathrm{~kg} /$ day corn-based concentrate (ratio of concentrate to rice straw $=95: 5$ on DM basis) for at least 14 days before rumen fluid collection. Ingredients and chemical composition of experimental diets are shown in Table 1 . The diets were offered twice daily at 09:00 and 17:00 h. The steer had free access to water and mineral blocks throughout the experiment.

\section{Treatments}

Three different doses of thymol (T.M. Semi Co., Ltd., Seoul, Korea), eugenol (T.M. Semi Co., Ltd., Seoul, Korea) and malate (Yongsan Chemicals, InC., Ulsan, Korea) were used. Treatments
Table 1. Ingredient and chemical composition of the experimental $\operatorname{diet}^{1)}$

\begin{tabular}{lc}
\hline Items & $\%$ of dry matter \\
\hline \hline Ingredient composition & \\
Rice straw & 4.78 \\
Concentrates & \\
Corn (ground) & 45.52 \\
Wheat & 39.04 \\
Soybean meal & 4.76 \\
Rapeseed meal & 1.90 \\
Molasses & 1.90 \\
Calcium phosphate & 1.43 \\
Salt & 0.38 \\
Vitamin-mineral additive & $2)$ \\
Lasalocid & 0.19 \\
Total & 0.10 \\
\hline
\end{tabular}

\begin{tabular}{lr}
\hline Chemical composition & \\
Dry matter & 86.53 \\
Crude protein & 18.12 \\
Ether extract & 3.46 \\
Crude fiber & 5.87 \\
Ash & 5.27 \\
Neutral detergent fiber & 26.83 \\
Acid detergent fiber & 7.12
\end{tabular}

1) A steer had free accessto water and mineral blocks (Rincal block, Daehan New Pham, Seoul, Korea; provided following nutrients per kg: I, 150 mg; Mn, 200 mg; S, 4,000 mg; Co, 100 mg; Fe, 2,000 mg; $\mathrm{Zn}, 100 \mathrm{mg}$; Ni, $50 \mathrm{mg}$; Cu, $100 \mathrm{mg}$; Mg, 3,000 mg; Ca, 2,000 mg; $\mathrm{Se}, 40 \mathrm{ug} ; \mathrm{NaCl}, 380 \mathrm{~g}$ ) throughout the experiment.

2) Provided following nutrients per $\mathrm{kg}$ of additive (Grobic-DC, Bayer HealthCare, Leverkusen, Germany): Vit. A, 2,650,000 IU; Vit. $\mathrm{D}_{3}$, 530,000 IU; Vit. E, 1,050 IU; Niacin, 10,000 mg; Mn, 4,400 mg; Zn, 4,400 mg; Fe, 13,200 mg Cu, 2,200 mg; I, 440 mg; Co, 440 mg.

of the experiment were as follows: Treatments of thymol were control (1g D-glucose/40 ml), T1 (1g D-glucose + $40 \mathrm{mg}$ thymol/ $40 \mathrm{ml}), \mathrm{T} 2(1 \mathrm{~g}$ D-glucose $+50 \mathrm{mg}$ thymol $/ 40 \mathrm{ml})$ and $\mathrm{T} 3(1 \mathrm{~g}$ D-glucose $+60 \mathrm{mg}$ thymol $/ 40 \mathrm{ml}) \quad[0,1,000,1,250$, and 1,500 $\mathrm{mg} / \mathrm{L}$, respectively]. Treatments of eugenol were control (1g D-glucose/40ml), E1 (1g D-glucose $+55 \mathrm{mg}$ eugenol/40 ml), E2 (1g D-glucose $+65 \mathrm{mg}$ eugenol $/ 40 \mathrm{ml})$ and E3 (1g D-glucose +75 $\mathrm{mg}$ eugenol/40 ml) $[0,1,375,1,625$, and $1,875 \mathrm{mg} / \mathrm{L}$, respectively]. Treatments of malate were control (1g D-glucose/ $40 \mathrm{ml}), \mathrm{M} 1$ (1g D-glucose $+25 \mathrm{mg}$ malate $/ 40 \mathrm{ml}), \mathrm{M} 2(1 \mathrm{~g}$ D-glucose $+50 \mathrm{mg}$ malate/40ml) and M3 (1g D-glucose $+100 \mathrm{mg}$ malate $/ 40 \mathrm{ml})[0$, $625,1,250$, and 2,500 $\mathrm{mg} / \mathrm{L}$, respectively]. 


\section{In vitro culture}

The procedure used was similar to that described by Tilley and Terry (1963). On d 14, the ruminal contents were obtained $2 \mathrm{~h}$ after feeding and squeezed through four layers of cheese cloth. The ruminal fluids were mixed in a 1 to 1 proportion with phosphate-bicarbonate buffer (McDougall, 1948), purged with anaerobic grade $\mathrm{CO}_{2}$. The representative aliquots $(40 \mathrm{ml})$ of the mixture of rumen fluid and the buffer were dispensed into each serum bottle $(60 \mathrm{ml})$ with bunsen valve system. The bottles were sealed with butyl rubber stoppers and aluminum caps to contain the gas pressure and placed in a $39^{\circ} \mathrm{C}$ shaking water bath (HB-205SW, Hanback Scientific Co., Seoul, Korea) and periodically mixed $(120 \mathrm{rpm})$. The incubation process of all culture fluid was performed in duplicate.

Liquid samples were withdrawn from each bottle to determine $\mathrm{pH}$ and analyze ammonia-N, VFA, lactic acid concentration, immediately before incubation $(0 \mathrm{~h})$ and at $1,2,3,5$, and $7 \mathrm{~h}$ after incubation. The $\mathrm{pH}$ was immediately measured with a $\mathrm{pH}$ meter (Corning Pinnacle model $530 \mathrm{pH}$ meter, Artington, UK). For ammonia-N and lactic acid analysis, samples $(6.2 \mathrm{~mL})$ were treated with $0.05 \mathrm{~mL}$ of a saturated solution of mercury (II) chloride (Sigma, MO, USA) and centrifuged at 2,000×g for 15 min at $4{ }^{\circ} \mathrm{C}$. Samples of $5.0 \mathrm{~mL}$ for VFA analyses were treated with $0.05 \mathrm{~mL}$ of a saturated solution of mercury (II) chloride (Sigma, MO, USA), $1 \mathrm{~mL}$ of metaphosphoric acid/water (25:75, $\mathrm{w} / \mathrm{v})$ and $0.2 \mathrm{~mL}$ of pivalic acid/water (10:90, w/v as an internal standard $(980 \mathrm{~g} / \mathrm{kg}$ purity, Sigma, MO, USA). After standing for $30 \mathrm{~min}$, samples were centrifuged at $2,000 \times \mathrm{g}$ for $15 \mathrm{~min}$ at $4{ }^{\circ} \mathrm{C}$. The cell-free supernatant was stored at $-20^{\circ} \mathrm{C}$.

\section{Chemical analyses}

\section{(1) Dry matter, NDF and ADF}

Experimental diets were dried by forced-air oven (at $60^{\circ} \mathrm{C}$, 48h), ground by a Wiley mill (Thomas scientific, Model 4, U.S.A.) and analyzed for moisture, CP, EE, and ash according to the procedure of Association of Official Analytical Chemists (AOAC, 1990). The concentration of NDF corrected for residual ash was determined with heat-stable amylase and sodium sulphate according to the method of Van Soest et al. (1991), while the content of $\mathrm{ADF}$ corrected for residual ash was determined according to the procedure of AOAC (1990).

\section{(2) Ammonia nitrogen}

Quantification of ammonia $\mathrm{N}$ was performed by UV spectrophotometer (Uvikon 923, Kontron, Milan, Italy). The supernatant samples were analyzed as described by Chaney and Marbach (1962). In brief, $0.02 \mathrm{~mL}$ of the supernatant was added into a glass tubes and then, $1 \mathrm{~mL}$ of phenol color reagent $(50 \mathrm{~g}$ phenol and $0.25 \mathrm{~g}$ sodium nitroferricyanide per $1 \mathrm{~L}$ of distilled water) and alkali-hypochlorite reagent $(25 \mathrm{~g} \mathrm{NaOH}$ and $16.8 \mathrm{~mL}$ sodium hypochlorite per $1 \mathrm{~L}$ of distilled water) were added. Blue color was produced after incubation for $15 \mathrm{~min}$ at $37^{\circ} \mathrm{C}$ using a water bath (HB-205SW, Hanback Scientific Co., Seoul, Korea) and then measured at $630 \mathrm{~nm}$ using a spectrophotometer (Uvikon 923, Kontron, Milan, Italy) after adding $8 \mathrm{~mL}$ of distilled water. Standards for ammonia $\mathrm{N}$ determination were prepared by dissolving $152.76 \mathrm{mg} \mathrm{NH}_{4} \mathrm{Cl}$ in $100 \mathrm{ml}$ equal distillate to a final concentration of $40 \mathrm{mg} \mathrm{NH}-\mathrm{N} / 100 \mathrm{~mL}$ (stock solution, $\mathrm{pH}$ 3.0). The dilution process was conducted by performing serial dilutions of $1: 2$ to end up with $20,10,5$, and $2.5 \mathrm{mg} \mathrm{NH}-\mathrm{N} / 100 \mathrm{~mL}$.

\section{(3) Volatile fatty acids}

Quantification of VFA was performed by a gas chromatography (CP-3800, Varian, CA, USA) with wall-coated open tubular-fused capillary column (length $25 \mathrm{~m}$, inside diameter $0.32 \mathrm{~mm}$, outside diameter $0.45 \mathrm{~mm}$, film thickness $0.3 \mathrm{~mm}, \mathrm{CP}-7485$, Varian, CA, USA). The procedure used was similar to that described by Erwin et al. (1961). A column temperature of $150^{\circ} \mathrm{C}$ was used with a nitrogen carrier gas at $100 \mathrm{~mL} / \mathrm{min}$ of flow rate. Temperature of both injector and detector was $130^{\circ} \mathrm{C}$. The hydrogen flow to the flame jet and air flow to the detector chamber were 40 and 400 $\mathrm{mL} / \mathrm{min}$, respectively. Calculations of VFA concentration were compared to the respective areas from VFA standard solution and quantified to a volume with the pivalic acid as internal standard factor. VFA standard solution was consisted of $54.41 \mathrm{mM}$ acetic acid (995 g/kg purity, Fluka, Seelze, Germany), $13.40 \mathrm{mM}$ propionic acid ( $995 \mathrm{~g} / \mathrm{kg}$ purity, Fluka, Seelze, Germany), 10.87 $\mathrm{mM}$ butyric acid (995 g/kg purity, Fluka, Seelze, Germany), 4.89 $\mathrm{mM}$ isobutyric acid (995 g/kg purity, Fluka, Seelze, Germany), $5.00 \mathrm{mM}$ valeric acid ( $980 \mathrm{~g} / \mathrm{kg}$ purity, Fluka, Seelze, Germany) and $5.00 \mathrm{mM}$ isovaleric acid $(980 \mathrm{~g} / \mathrm{kg}$ purity, Fluka, Seelze, Germany)

\section{(4) Lactic acid}

Quantification of lactic acid was performed by liquid 
chromatography (Alliance, Waters, U.S.A) / mass spectrometry (ZQ-4000, Waters, U.S.A). The procedure used was similar to that described by Martin and Park (1996). Conditions of liquid chromatograph were as follows. Flow rate: $0.3 \mathrm{ml} / \mathrm{min}$, PDA (2996 Photodiode Array Detector, Waters, U.S.A): 200 500 nm, column: Xterra MS C18 $3.5 \mathrm{um}(3.0 \times 150 \mathrm{~nm})$, mobile phase: $0.4 \%$ formic acid, injection volume: $3 / i$, run time: $5 \mathrm{~min}$. Conditions of mass spectrometer were as follows. Lactic acid (4-6937, SUPELCO) m/z: 89 (ES-), capillary (kv): 3.2 (ES-), cone (v): 25, extractor (v): 2, RF Len (v): 0.0, temp./Source $\left({ }^{\circ} \mathrm{C}\right): 130$, desolvation $\left({ }^{\circ} \mathrm{C}\right)$ : 350 , gas flow $/$ desolvation $(\mathrm{r} / \mathrm{hr}): 600$, cone (r/hr): 50 .

\section{Statistical analyses}

Data obtained from the experiment was subjected to statistical analysis using the GLM procedure of SAS ver. 9.1 (SAS, 2002) according to a statistical model described below:

$\mathrm{Y}_{\mathrm{ij}}=\mu+\mathrm{H}_{\mathrm{i}}+\mathrm{T}_{\mathrm{j}}+(\mathrm{H} \times \mathrm{T})_{\mathrm{ij}}+\mathrm{e}_{\mathrm{ij}}$

Where $Y_{i}, \mu, H_{i}, T_{j},(H \times T)_{i j}$ and $e_{i j}$ are the response, overall mean, mean effect of incubation time, mean effect of treatment, interaction between incubation time and treatment, and random residual error, respectively.

Duncan's multiple range test was used to interpret any significant differences among the mean values of the treatment. Statistical significance was set at $\mathrm{P}<0.05$.

\section{RESULTS AND DISCUSSION}

The effects of thymol on $\mathrm{pH}$, ammonia nitrogen, volatile fatty acid (VFA) and lactic acid concentrations in vitro were shown in Table 2. Thymol is one of the major compounds of essential oils of thyme (Thymus vulgaris) and oregano (Origanum vulgaris Dorman and Deans, 2000). It is a monoterpene [5-methyl-2(1-methylethyl) phenol; $\mathrm{C}_{10} \mathrm{H}_{14} \mathrm{O}$ ] with strong antimicrobial activity against a wide range of gram-positive and -negative bacteria (Burt, 2004). The effects of thymol on rumen fermentation showed a dose-dependent manner. Compared with the control, thymol at T1, T2 and T3 (1,000, 1,250, and 1,500 $\mathrm{mg} / \mathrm{L}$, respectively) reduced total VFA concentration and the concentration of propionate, acetate, and branched-chain VFA (BCVFA), but increased ammonia $\mathrm{N}$ concentration, acetate to

Table 2. Effects of thymol on $\mathrm{pH}$, ammonia-N, volatile fatty acid (VFA) and lactic acid concentrations in vitro (mean value)

\begin{tabular}{|c|c|c|c|c|c|}
\hline \multirow{2}{*}{ Items } & \multicolumn{4}{|c|}{ Treatments $^{1)}$} & \multirow{2}{*}{$\mathrm{SEM}^{2}$} \\
\hline & Control & $\mathrm{T} 1$ & $\mathrm{~T} 2$ & $\mathrm{~T} 3$ & \\
\hline $\mathrm{pH}$ & $5.48^{\mathrm{d}}$ & $5.74^{\mathrm{c}}$ & $5.84^{\mathrm{b}}$ & $5.96^{\mathrm{a}}$ & 0.02 \\
\hline Ammonia- $\mathrm{N}, \mathrm{mg} / \mathrm{L}$ & $17.63^{d}$ & $65.91^{\mathrm{c}}$ & $73.39^{\mathrm{b}}$ & $86.21^{\mathrm{a}}$ & 1.14 \\
\hline \multicolumn{6}{|l|}{ VFA, mM } \\
\hline Acetate & $72.10^{\mathrm{a}}$ & $63.10^{\mathrm{ab}}$ & $57.37^{\mathrm{ab}}$ & $54.62^{\mathrm{b}}$ & 3.95 \\
\hline Propionate & $56.12^{\mathrm{a}}$ & $40.38^{\mathrm{b}}$ & $37.78^{\mathrm{b}}$ & $35.15^{\mathrm{b}}$ & 1.89 \\
\hline Isobutyrate & $1.07^{\mathrm{a}}$ & $0.93^{\mathrm{ab}}$ & $0.94^{\mathrm{ab}}$ & $0.92^{\mathrm{b}}$ & 0.04 \\
\hline Butyrate & $15.76^{\mathrm{a}}$ & $12.40^{\mathrm{b}}$ & $12.17^{\mathrm{b}}$ & $11.66^{\mathrm{b}}$ & 0.68 \\
\hline Isovalerate & 1.75 & 1.64 & 1.56 & 1.56 & 0.10 \\
\hline Valerate & $4.44^{\mathrm{a}}$ & $3.50^{\mathrm{b}}$ & $3.22^{\mathrm{b}}$ & $3.04^{\mathrm{b}}$ & 0.19 \\
\hline Total & $152.77^{\mathrm{a}}$ & $119.92^{\mathrm{b}}$ & $117.74^{\mathrm{b}}$ & $111.56^{\mathrm{b}}$ & 6.37 \\
\hline A : P ratio ${ }^{3)}$ & $1.37^{\mathrm{b}}$ & $1.65^{\mathrm{a}}$ & $1.69^{\mathrm{a}}$ & $1.72^{\mathrm{a}}$ & 0.03 \\
\hline Lactic acid, mM & $4.66^{\mathrm{a}}$ & $4.90^{\mathrm{a}}$ & $4.64^{\mathrm{a}}$ & $4.32^{\mathrm{b}}$ & 0.09 \\
\hline
\end{tabular}

\footnotetext{
1) Control: $0 \mathrm{mg}$ thymol/L; T1: $1,000 \mathrm{mg}$ thymol/L; T2: 1,250 $\mathrm{mg}$ thymol/L; and T3: $1,500 \mathrm{mg}$ thymol/L.

2) SEM: standard error of mean.

3) Acetate : propionate ratio.

${ }^{a, b, c, d}$ Means with different superscripts within the same row are significantly different $(\mathrm{P}<0.05)$.
} 
propionate ratio, and rumen $\mathrm{pH}$. The lactic acid concentration of T3 was significantly lower $(\mathrm{P}<0.05)$ compared with other treatments. The ruminal $\mathrm{pH}$ after $1 \mathrm{~h}$ post-incubation was significantly different $(\mathrm{P}<0.05)$ among the treatments, being higher in proportion to the dose level of thymol (Fig. 1A). The concentration of the total VFA was significantly lower $(\mathrm{P}<0.05)$ in thymol treatments than in control at 5 and $7 \mathrm{~h}$ after incubation (Fig. 1B). The concentration of lactic acid for the T3 remained the lowest among the treatments at 5 and $7 \mathrm{~h}$ after incubation (Fig. 1C). Different level of thymol addition had negative effects on rumen microbial fermentation such as reduced VFA production, but positive effects on ruminal $\mathrm{pH}$. Several studies demonstrated that thymol has wide-spectrum antimicrobial activity, inhibiting
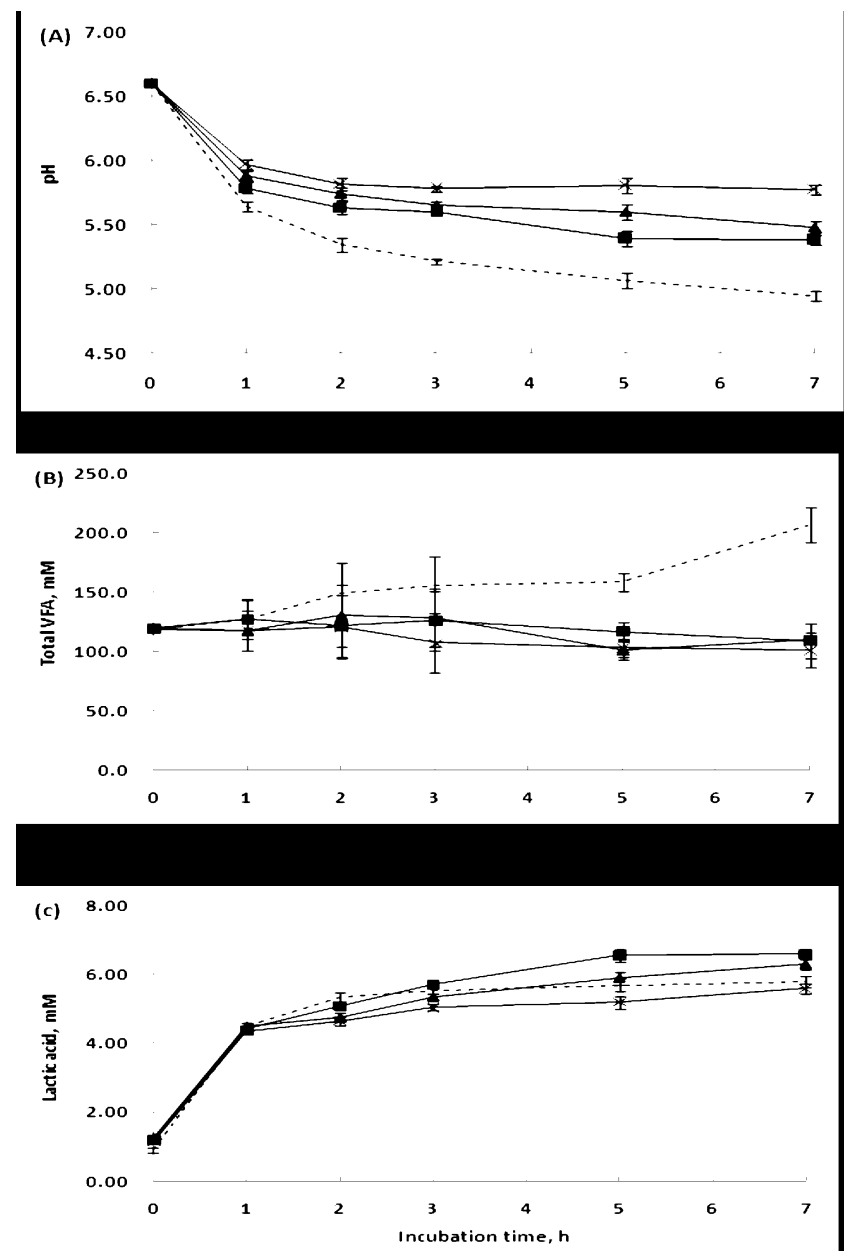

Fig. 1. Changes in $\mathrm{pH}(\mathrm{A})$, concentrations of total volatile fatty acid (B) and lactic acid (C) on different doses of thymol; Control treated with $0 \mathrm{mg} / \mathrm{L}$ of thymol (---), treatment 1 treated with $1,000 \mathrm{mg} / \mathrm{L}$ of thymol ( $\mathbf{m})$, treatment 2 treated with $1,250 \mathrm{mg} / \mathrm{L}$ of thymol $(\Delta)$, and treatment 3 treated with $1,500 \mathrm{mg} / \mathrm{L}$ of thymol $(x)$. gram-positive and -negative bacteria due to its capacity to act as membrane permeabilizer (Helander et al., 1998; Dorman and Deans, 2000; Walsh et al., 2003; Castillejos et al., 2006). Evans and Martin (2000) also reported that the addition of $400 \mathrm{mg} / \mathrm{L}$ of thymol, a common essential oil derived from Thyme and Oregano plants, increased the $\mathrm{pH}$ in $24 \mathrm{~h}$ in vitro batch cultures of mixed rumen bacteria, but no effects were reported at lower doses (i.e., 50, 100, and $200 \mathrm{mg} / \mathrm{L}$ ). More recently, Castillejos et al. (2006) evaluated the effects of increasing doses $(0,5,50,500$, and 5,000 $\mathrm{mg} / \mathrm{L}$ ) of thymol on ruminal fermentation in a $24 \mathrm{~h}$ in vitro batch culture of ruminal bacteria. At the highest dose (i.e., 5,000 mg/L), $\mathrm{pH}$ was increased, but no effects were observed at lower doses. In the present study, thymol additions had a positive effect on the

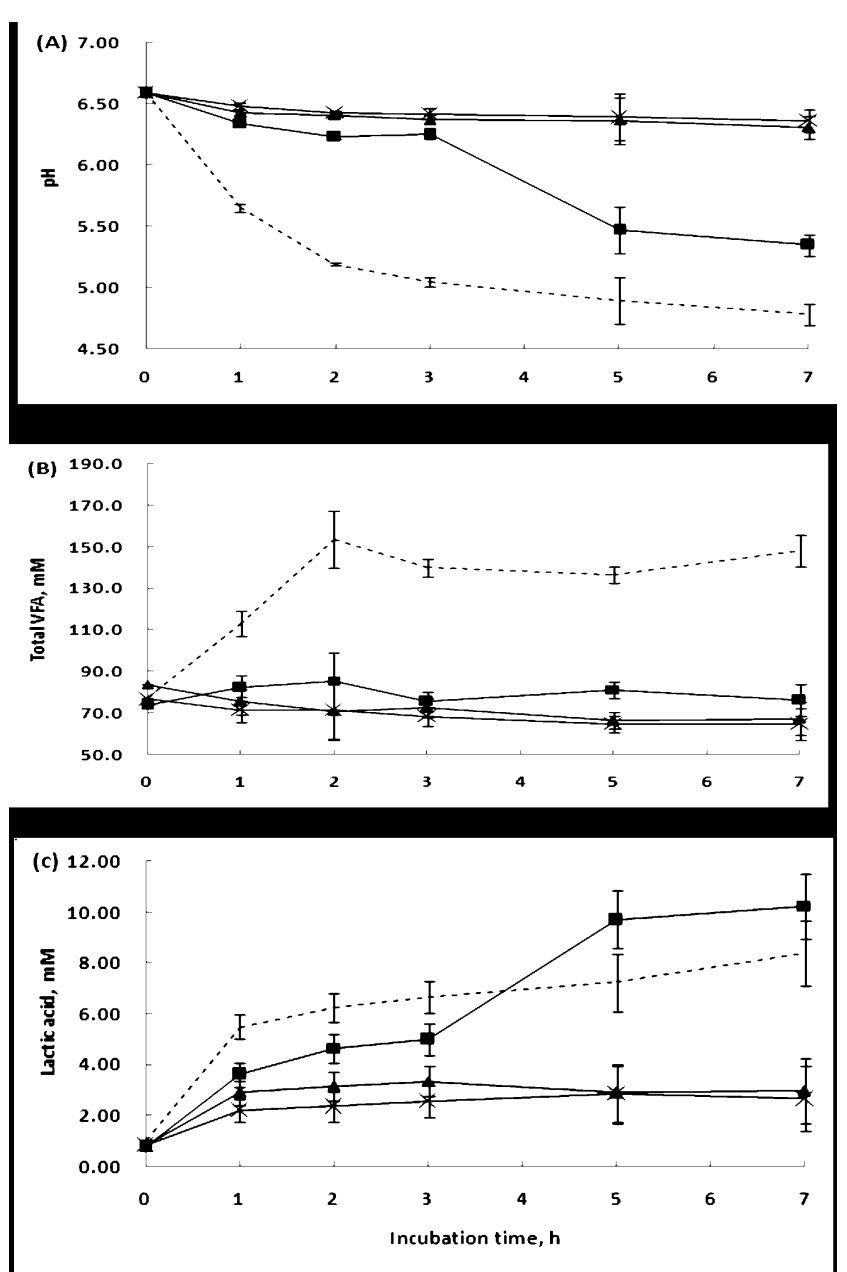

Fig. 2. Changes in $\mathrm{pH}(\mathrm{A})$, concentrations of total volatile fatty acid (B) and lactic acid (C) on different doses of eugenol; Control treated with $0 \mathrm{mg} / \mathrm{L}$ of eugenol (---), treatment 1 treated with $1,375 \mathrm{mg} / \mathrm{L}$ of eugenol $(\mathbf{m})$, treatment 2 treated with $1,625 \mathrm{mg} / \mathrm{L}$ of eugenol $(\Delta)$, and treatment 3 treated with $1,875 \mathrm{mg} / \mathrm{L}$ of eugenol $(x)$. 
stability of ruminal $\mathrm{pH}$, and decrease of lactic acid was affected only at the T3 treatment. On the other hand, thymol additionshad negative effects on rumen microbial fermentation such as reduced VFA production. Therefore, the optimal dose may be difficult to define because there is a narrow range of doses between observing some effects (reduction in lactate concentration and increase in rumen $\mathrm{pH}$ ) and having negative effects (reduction in total VFA concentration). Evans and Martin (2000) observed that thymol inhibited the growth of both Selenomonas ruminantium and Streptococcus bovis, respectively. They suggested that thymol disrupted membrane integrity and altered glucose transport.

The effects of eugenol on $\mathrm{pH}$, ammonia nitrogen, volatile fatty acid (VFA) and lactic acid concentrations in vitro were shown in Table 3. Eugenol (4-allyl-2-methoxyphenol; $\mathrm{C}_{10} \mathrm{H}_{12} \mathrm{O}_{2}$ ) is a phenolic compound with wide-spectrum antimicrobial activity against gram-positive and -negative bacteria. It is one of the main active components in clove bud(Eugenia caryophyllus or Syzygium aromaticum) and cinnamon (Cinnamomum cassia) oils
(Davidson and Naidu, 2000; Dorman and Deans, 2000; Walsh et al., 2003).

Eugenol at E1, E2 and E3 (1,375, 1,625, and 1,875 mg/L, respectively) reduced total VFA concentration and the concentrations of propionate, acetate, and BCVFA concentration, but increased the ammonia- $\mathrm{N}$ concentration, acetate to propionate ratio, and rumen $\mathrm{pH}$. The lactic acid concentration with $\mathrm{E} 2$ and $\mathrm{E} 3$ were significantly lower $(\mathrm{P}<0.05)$ compared with that of control and E1. The ruminal $\mathrm{pH}$ after $1 \mathrm{~h}$ post-incubation was significantly different $(\mathrm{P}<0.05)$ among the treatments, being higher in eugenol additions than in control (Fig. 2A). The concentration of the total VFA was significantly lower $(\mathrm{P}<0.05)$ in eugenol treatments than in control (Fig. 2B). After $2 \mathrm{~h}$ incubation, the concentrations of lactic acid concentrations in the E2 and the E3 remained significantly lower $(\mathrm{P}<0.05)$ compared with control and E1. In treatment 1 , the products of lactic acid at $5 \mathrm{~h}$ after incubation was increased due to decreasing pH (Fig. 2A, C).

The benefits of eugenol on rumen microbial fermentation were

Table 3. Effects of eugenol on $\mathrm{pH}$, ammonia-N, volatile fatty acid (VFA) and lactic acid concentrations in vitro (mean value)

\begin{tabular}{|c|c|c|c|c|c|}
\hline \multirow{2}{*}{ Items } & \multicolumn{4}{|c|}{ Treatments $^{1)}$} & \multirow{2}{*}{$\mathrm{SEM}^{2}$} \\
\hline & Control & E1 & E2 & E3 & \\
\hline $\mathrm{pH}$ & $5.36^{\mathrm{c}}$ & $6.04^{\mathrm{b}}$ & $6.42^{\mathrm{a}}$ & $6.45^{\mathrm{a}}$ & 0.05 \\
\hline Ammonia-N, mg/L & $41.06^{\mathrm{b}}$ & $189.58^{\mathrm{a}}$ & $196.99^{\mathrm{a}}$ & $197.61^{\mathrm{a}}$ & 5.52 \\
\hline \multicolumn{6}{|l|}{ VFA, mM } \\
\hline Acetate & $65.40^{\mathrm{a}}$ & $45.55^{\mathrm{b}}$ & $41.04^{\mathrm{b}}$ & $40.27^{\mathrm{b}}$ & 1.90 \\
\hline Propionate & $43.21^{\mathrm{a}}$ & $19.34^{\mathrm{b}}$ & $18.49^{\mathrm{b}}$ & $18.36^{\mathrm{b}}$ & 0.88 \\
\hline Isobutyrate & $0.82^{\mathrm{a}}$ & $0.77^{\mathrm{ab}}$ & $0.73^{\mathrm{ab}}$ & $0.70^{\mathrm{b}}$ & 0.03 \\
\hline Butyrate & $13.76^{\mathrm{a}}$ & $9.72^{\mathrm{b}}$ & $7.95^{\mathrm{c}}$ & $7.26^{\mathrm{c}}$ & 0.48 \\
\hline Isovalerate & $1.30^{\mathrm{a}}$ & $1.26^{\mathrm{ab}}$ & $1.20^{\mathrm{ab}}$ & $1.15^{\mathrm{b}}$ & 0.05 \\
\hline Valerate & $3.61^{\mathrm{a}}$ & $3.18^{\mathrm{b}}$ & $2.40^{\mathrm{c}}$ & $2.02^{\mathrm{c}}$ & 0.12 \\
\hline Total & $128.09^{\mathrm{a}}$ & $79.82^{\mathrm{b}}$ & $71.77^{\mathrm{bc}}$ & $69.76^{\mathrm{c}}$ & 3.40 \\
\hline A : P ratio ${ }^{3)}$ & $1.55^{\mathrm{c}}$ & $2.44^{\mathrm{a}}$ & $2.26^{\mathrm{b}}$ & $2.22^{\mathrm{b}}$ & 0.03 \\
\hline Lactic acid, mM & $5.85^{\mathrm{a}}$ & $5.70^{\mathrm{a}}$ & $2.71^{\mathrm{b}}$ & $2.27^{\mathrm{b}}$ & 0.34 \\
\hline
\end{tabular}

\footnotetext{
1) Control: $0 \mathrm{mg}$ eugenol/L; E1: 1,375 mg eugenol/L; E2: 1,625 mg eugenol/L; and E3: $1,875 \mathrm{mg}$ eugenol/L.

2) SEM: standard error of mean

3) Acetate : propionate ratio.

a,b,c Means with different superscripts within the same row are significantly different $(\mathrm{P}<0.05)$.
} 
tested in vitro by Castillejos et al. (2006). In a 10:90 beef-type diet based on straw, corn grain, barley grain, and soybean meal, eugenol reduced the total VFA concentration and proportion of propionate, and increased the proportion of acetate and the acetate to propionate ratio. In the present study, eugenol addition had a negative effect (i.e. reduced VFA production) on rumen microbial fermentation and the fermentation profile may not be desirable for beef production. But eugenol additives had positive effects on stability of ruminal $\mathrm{pH}$ and decrease of lactic acid. It would seem likely that eugenol might inhibit the Streptococcus bovis and Lactobacillus sp., producing large amounts of lactic acid. The bacteriostatic and bacteriocidal concentrations of the three most-inhibitory essential oils, i.e. cinnamaldehyde is one of the main active component in cinnamon (C cassia), eugenol is one of the main active component in clove (Syzygium aromaticum L.) and thymol is one of the main active component in thyme (Thymus vulgaris L.), were generally lower for the gram-positive bacteria than for the gram-negative bacteria (Smith-Palmer et al.,
1998; Greathead, 2003). Thus, it was concluded that grampositive bacteria were more sensitive to essential oils than gram-negative bacteria. Due to the ability of eugenol to inhibit ruminal bacteria that produce lactic acid, it could be an effective feed additive in reducing the acidosis incidence by decreasing lactic acid production and increasing $\mathrm{pH}$, although eugenol have negative effects (reduction in total VFA concentration and proportion of propionate, and increased the proportion of acetate and the acetate to propionate ratio). Therefore, more research is needed to determine the optimal dose and evaluate the effect of this additive on in vivo rumen fermentation in finishing steers.

The effects of malate on $\mathrm{pH}$, ammonia nitrogen, volatile fatty acid (VFA) and lactic acid concentrations in vitro were shown in Table 4. Malate is commonly found in biological tissues because it is intermediates of the citric acid cycle (Lehninger, 1975). Some strictly anaerobic bacteria use a reductive or reverse citric acid cycle known as the succinate-propionate pathway to synthesize succinate or propionate (Gottschalk, 1986). Malate is key

Table 4. Effects of malate on $\mathrm{pH}$, ammonia- $\mathrm{N}$, volatile fatty acid (VFA) and lactic acid concentrations in vitro (mean value)

\begin{tabular}{|c|c|c|c|c|c|}
\hline \multirow{2}{*}{ Items } & \multicolumn{4}{|c|}{ Treatments $^{1)}$} & \multirow{2}{*}{$\mathrm{SEM}^{2)}$} \\
\hline & Control & M1 & M2 & M3 & \\
\hline $\mathrm{pH}$ & $5.79^{\mathrm{a}}$ & $5.79^{\mathrm{a}}$ & $5.78^{\mathrm{a}}$ & $5.74^{b}$ & 0.01 \\
\hline Ammonia-N, mg/L & $323.42^{\mathrm{d}}$ & $344.77^{\mathrm{c}}$ & $356.12^{\mathrm{b}}$ & $384.47^{\mathrm{a}}$ & 2.37 \\
\hline \multicolumn{6}{|l|}{ VFA, mM } \\
\hline Acetate & 89.50 & 94.31 & 92.76 & 88.62 & 4.07 \\
\hline Propionate & 44.26 & 46.60 & 46.52 & 43.44 & 1.77 \\
\hline Isobutyrate & 1.68 & 1.70 & 1.73 & 1.66 & 0.07 \\
\hline Butyrate & 37.44 & 38.07 & 38.08 & 36.63 & 1.47 \\
\hline Isovalerate & 4.96 & 5.05 & 5.15 & 4.96 & 0.22 \\
\hline Valerate & 4.29 & 4.38 & 4.39 & 4.01 & 0.17 \\
\hline Total & 182.11 & 190.09 & 188.62 & 179.30 & 7.50 \\
\hline A $:$ P ratio ${ }^{3)}$ & 2.11 & 2.09 & 2.06 & 2.12 & 0.04 \\
\hline Lactic acid, mM & $3.03^{\mathrm{a}}$ & $3.07^{\mathrm{a}}$ & $3.00^{\mathrm{a}}$ & $2.73^{\mathrm{b}}$ & 0.04 \\
\hline
\end{tabular}

1) Control: $0 \mathrm{mg}$ malate $/ \mathrm{L}$; M1: $625 \mathrm{mg}$ malate/L; M2: $1,250 \mathrm{mg}$ malate $/ \mathrm{L}$; and M3: 2,500 mg malate/L.

2) SEM: standard error of mean.

3) Acetate : propionate ratio.

a,b,c,d Means with different superscripts within the same row are significantly different $(\mathrm{P}<0.05)$. 
intermediates in the succinate-propionate pathway, and Selenomonas ruminantium uses this pathway. It stimulates lactic acid uptake by Selenomonas ruminantium, the main bacteria within the rumen and improves the ruminal environment and increases propionate production (Callaway and Martin, 1996; Martin, 1998).

Malate at M1, M2 and M3 (625, 1,250, and 2,500 mg/L, respectively) increased the ammonia- $\mathrm{N}$ concentration. But total
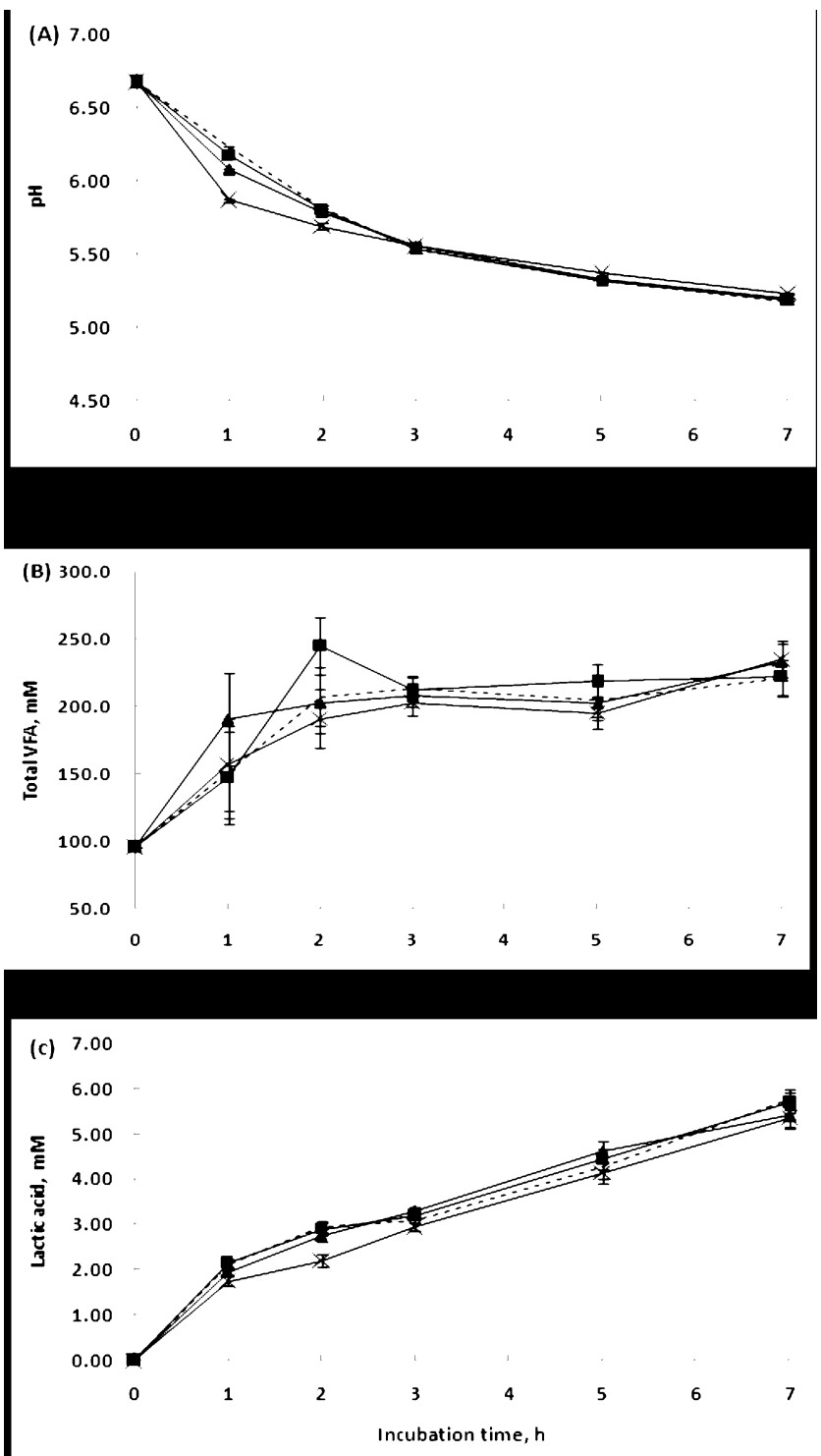

Fig. 3. Changes in $\mathrm{pH}$ (A), concentrations of total volatile fatty acid (B) and lactic acid (C) on different doses of malate; Control treated with $0 \mathrm{mg} / \mathrm{L}$ of malate (---), treatment 1 treated with $625 \mathrm{mg} / \mathrm{L}$ of malate $(-)$, treatment 2 treated with $1,250 \mathrm{mg} / \mathrm{L}$ of malate $(\mathbf{\Delta})$, and treatment 3 treated with $2,500 \mathrm{mg} / \mathrm{L}$ of malate $(x)$.
VFA concentration, the proportion of propionate, acetate, and BCVFA concentration, and acetate to propionate ratio were unaffected by malate addition. The lactic acid concentration at M3 treatment was significantly lower $(\mathrm{P}<0.05)$ compared with other treatments. Changes in $\mathrm{pH}$, total VFA, and lactic acid were not different among the treatments during $7 \mathrm{~h}$ incubation(Fig. 3). Increased levels of malate addition did not affect ruminal $\mathrm{pH}$ and total VFA concentration, but showed a positive effect on lactic acid only with the M3. Martin et al. (1995) reported that 4, 8, and $12 \mathrm{mM}$ (approximately 500, 1000, and $1600 \mathrm{mg} / \mathrm{L}$ ) DL-malate stimulated ruminal microorganism fermentation by increasing concentrations of propionate and total VFA as well as final $\mathrm{pH}$. Indeed, Martin et al. (1999) reported that ruminal $\mathrm{pH}$ linearly increased $(\mathrm{P}<0.01)$ with DL-malate treatments(approximately 500, 1000 , and $1600 \mathrm{mg} / \mathrm{L}$ ) and all concentrations of DL-malate were effective in reducing the drop in ruminal $\mathrm{pH}$ normally seen 1 to 2 $\mathrm{h}$ after feeding. Therefore, supplementing malate in the finishing diets for Hanwoo cattle might be effective in reducing lactic acid and increasing ruminal $\mathrm{pH}$.

The results of the experiment suggested that, when thymol, eugenol or malate was used at optimal doses, the rumen fermentation was likely to improve. In addition, the combination of these alternatives for antibiotics with different mechanisms of action may result in synergistic effects that enhance rumen fermentation.

\section{REFERENCES}

1. Association of Official Analytical Chemists. 1990. Official Methods of Analysis, Association of Official Analytical Chemists, Washington, D. C.

2. Benchaar, C., Petit, H. V., Berthiaume, R., Ouellet, D. R., Chiquette, J. and Chouinard, P. Y. 2007. Effects of essential oils on digestion, ruminal fermentation, rumen microbial populations, milk production, and milk composition in dairy cows fed alfalfa silage or corn silage. J. Dairy Sci. 90:886897.

3. Bevans, D. W., Beauchemin, K. A., Schwartzkopf-Genswein, K. S., McKinnon, J. J. and McAllister, T. A. 2005. Effect of rapid or gradual grain adaptation on subacute acidosis and feed intake by feedlot cattle. J. Anim. Sci. 83:1116-1132.

4. Borchers, R. 1965. Proteolytic activity of rumen fluid in vitro. J. Anim. Sci. 24:1033-1038 
5. Burt, S. 2004. Essential oils: Their antibacterial properties and potential applications in foods-A review. Int. J. Food Microbiol. 94:223-253.

6. Busquet, M., Calsamiglia, S., Ferret, A. and Kamel, C. 2006. Plant extracts affect in vitro rumen microbial fermentation. J. Dairy Sci. 89:761-771.

7. Callaway, T. R. and Martin, S. A. 1996. Effect of organic acid and monensin treatment on in vitro mixed ruminal microorganism fermentation of cracked corn. J. Anim Sci. 74: 1982-1989.

8. Castillejos, L., Calsamiglia, S. and Ferret, A. 2006. Effect of essential oils active compounds on rumen microbial fermentation and nutrient flow in in vitro systems. J. Dairy Sci. 89: 2649-2658.

9. Chaney, A. L. and Marbach, E. P. 1962. Modified reagents for determination of urea and ammonia. Clin. Biochem. 8:130-137.

10. Chao, S. C. and Young, D. G. 2000. Screening for inhibitory activity of essential oils on selected bacteria, fungi and viruses. J. Essent. Oil Res. 12:639-649.

11. Davidson, P. M. and Naidu, A. S. 2000. Phyto-phenols. Pages 265-293 in Natural Food Antimicrobial Systems. A. S. Naidu, ed. CRC Press, Boca Raton, FL.

12. Dawson, D. A. and Allison, M. J. 1988. Digestive disorders and nutritional toxicity. Pages $445-459$ in The rumen microbial ecosystem. P. N. Hobson, ed. Elsevier Science Publishers Ltd., London, U.K

13. Dawson, K. A., Rasmussen, M. A. and Allison, M. J. 1997. Digestive disorders and nutritional toxicity. In: Hobson, P. N., and C. S. Stewart. (eds), The rumen microbial ecosystem, 2nd edn, pp. 633-660. Blackie Academic and Professional, London.

14. Dorman, H. J. D. and Deans, S. G. 2000. Antimicrobial agents from plants: Antibacterial activity of plant volatile oils. J. Appl. Microbiol. 88:308-316.

15. Erwin, E. S., Marco, G. T. and Emery, E. M. 1961. Volatile fatty acid analysis of blood and rumen fluid by gas chromatography. J. Dairy Sci. 44:1768-1771.

16. Evans, J. D. and Martin, S. A. 2000. Effects of thymol on ruminal microorganisms. Curr. Microbiol. 41:336-340.

17. Gershenzon, J. and Croteau, R. 1991. Terpenoids. Pages 165-219 in Herbivores: Their Interactions with Secondary Plant Metabolites. Vol. 1. G. A. Rosenthal, and M. R. Berenbaum, ed. Academic Press, San Diego, CA.

18. Gottschalk, G. 1986. Bacterial Metabolism (2nd Ed.). Springer
Verlag, New York.

19. Greathead, H. 2003. Plants and plant extracts for improving animal productivity. Proceedings of the Nutrition Society. 62: 279-290.

20. Helander, I. M., Alakomi, H., Latva-Kala, K., MattilaSandholm, T., Pol, I., Smid, E. J., Gorris, L. G. M. and Wright, A. 1998. Characteritzation of the action of selected essential oil components on gram-negative bacteria. J. Agric. Food Chem. 46:3590-3595.

21. Lehninger, A. L. 1975. Biochemistry (2nd Ed.). Worth Publishers, New York.

22. Martin, S. A. 1998. Manipulation of ruminal fermentation with organic acids: A review. J. Anim. Sci. 76:3123-3132.

23. Martin, S. A. and Park, C. M. 1996. Effect of extracellular hydrogen on organic acid utilization by the ruminal bacterium Selenomonas ruminantium. Curr. Microbiol. 32:327-331.

24. Martin, S. A. and Streeter, M. N. 1995. Effect of malate on in vitro mixed ruminal microorganism fermentation. J. Anim. Sci. 73:2141-2145.

25. Martin, S. A., Streeter, M. N., Nisbet, D. J., Hill, G. M. and Williams, S. E. 1999. Effects of DL-malate on ruminal metabolism and performance of cattle fed a high-concentrate diet. J. Anim. Sci. 77:1008-1015

26. MeDougal, E. I. 1948. Studies on ruminant saliva. 1. The composition and output of sheep's saliva. Biochem. J. 43:99103.

27. Montano, M .F., Chai, W., Zinn-Ware, T. E. and Zinn, R. A. 1999. Influence of malic acid supplementation on ruminal $\mathrm{pH}$, lactic acid utilization, and digestive function in steers fed high-concentrate finishing diets. J. Anim. Sci. 77:780-784.

28. Nisbet, D. J. and Martin, S. A. 1994. Factors affecting Llactate utilization by Selenomonas ruminantium. J. Anim. Sci. 72:1355-1361.

29. Panizzi, L., Flamini, G., Cioni, P. L. and Moreli, I. 1993. Composition and antimicrobial properties of essential oils of four mediterranean Lamiaceae. J. Ethnopharmacol. 39:167-170.

30. Rural Development Administration. 2007. The standard farming textbook. Hanwoo. 6th edition.

31. Russell, J. B. and Hino, T. 1985. Regulation of lactate production in Streptococcus bovis. A spiraling effect that contributes to rumen acidosis. J. Dairy. Sci. 68:1712-1721.

32. SAS Institute, 2002. SAS ${ }^{\circledR}$ User's guide: Statistics. Version 9.1 Edition. Statistical Analysis Systems Institute Inc., Cary, NC. 
33. Slyter, L. L. 1976. Influence of acidosis on rumen function. J. Animal Sci.43:910-929.

34. Smith-Palmer, A., Stewart, J. and Fyfe, L. 1998. Antimicrobial properties of plant essential oils and essences against five important food-borne pathogens. Letters in Applied Microbiology. 26:118-122.

35. Tilley, J. M. A. and Terry, R. A. 1963. A two-stage technique for the in vitro digestion of forage crops J. Brit. Grassland Soc. 18:104-111.

36. Van Soest, P. J., Robertson, J. B. and Lewis, B. A. 1991.
Methods of dietary fiber, neutral detergent fiber and non-starch poly-saccharides in relation to animal nutrition. J. Dairy Sci. 74:3583-3597.

37. Walsh, S. E., Maillard, J. Y., Russell, A. D., Catrenith, C. E., Charbonneau, D. L. and Bartolo, R. G. 2003. Activity and mechanisms of action of selected biocidal agents on grampositive and negative bacteria. J. Appl. Microbiol. 94:240-247. (Received September 30, 2009; Revised December 7, 2009; Accepted December 10, 2009) 